\title{
Engineering SIV-resistant macaque hematopoietic stem cells and CD4+ T cells with CCR5-specific zinc-finger nucleases
}

\author{
G Bonello, P Lentz, M Salas, M Cepeda, R White, M Gauduin* \\ From AIDS Vaccine 2012 \\ Boston, MA, USA. 9-12 September 2012
}

\section{Background}

CCR5 is the major HIV co-receptor, and individuals homozygous for a 32-bp deletion in CCR5 are resistant to infection by CCR5-tropic HIV-1. Zinc finger nuclease (ZFN) technology is a class of engineered DNA-binding proteins facilitating targeted genome editing by binding to a user-specific locus and causing a double-strand break in the region of interest. As a result, the gene of interest targeted by ZFN cleavage is disrupted. We investigated the ability of a Ccr5 gene-specific ZFN to establish SIV-resistant CD4+ T cells and hematopoietic progenitor cells isolated from macaques.

\section{Methods}

Bone marrow and blood samples were obtained from ten naïve uninfected rhesus macaques. Immunomagnetic enrichments were performed to isolate hematopoietic stem/progenitor cells and CD4+ T cells using magneticbeads. Purified cells were nucleofected with RNAs encoding for a Ccr5-specific ZFNs.

\section{Results}

We successfully engineered CCR5-modified macaque CD4 $+\mathrm{T}$ lymphocytes that were resistant to in vitro infection with SIVmac239, SIVmac251, and CCR5-tropism SIVagm. CD4+ T lymphocytes that incorporated RNAs encoding for the Ccr5-specific set of ZFNs marked resistance to SIV infection as showed by lack of p27 expression in culture supernatants. Infection of non-modified CD4+ T lymphocytes led to significant $\mathrm{p} 27$ production from day 5 postinfection with a pick at day 7 post-infection. We developed and optimized the conditions for proper isolation, expansion and in vitro differentiation of macaque hematopoietic

Texas Biomedical Research Institute, San Antonio, TX, USA stem cells to be used for the generation of SIV-resistant macaque hematopoietic stem cells using our ZFNs. We successfully engineered CD34+ hematopoietic stem cells using nucleofection of RNAs encoding for a Ccr5-specific ZFNs.

\section{Conclusion}

We demonstrated the feasibility of using ZFN technology to establish CD4+ and hematopoietic stem cells resistant to SIV infection in macaque model. The generation of a nonhuman primate model using this modern molecularbased strategy might significantly help in the design of new therapies to prevent viral infection in human.

Published: 13 September 2012

doi:10.1186/1742-4690-9-S2-P226

Cite this article as: Bonello et al:: Engineering SIV-resistant macaque hematopoietic stem cells and CD4+ T cells with CCR5-specific zincfinger nucleases. Retrovirology 2012 9(Suppl 2):P226.

Submit your next manuscript to BioMed Central and take full advantage of:

- Convenient online submission

- Thorough peer review

- No space constraints or color figure charges

- Immediate publication on acceptance

- Inclusion in PubMed, CAS, Scopus and Google Scholar

- Research which is freely available for redistribution

\section{() Biomed Central}

(c) 2012 Bonello et al; licensee BioMed Central Ltd. This is an Open Access article distributed under the terms of the Creative Commons Attribution License (http://creativecommons.org/licenses/by/2.0), which permits unrestricted use, distribution, and reproduction in any medium, provided the original work is properly cited. 